\title{
SIMBOL DAN MAKNA RITUAL YAQOWIYU DI JATINOM KLATEN
}

\author{
Mona Erythrea Nur Islami \\ Dosen Sekolah Tinggi Pariwisata AMPTA Yogyakarta \\ M. Ikhsanudin \\ Dosen STIQ Annur Yogyakarta
}

\begin{abstract}
Yaqowiyu is one syncretism practice that still survives to this day in Indonesia. Ritual held every "Sapar" evolved since this days of Islamic Mataram. The purpose of the ritual is to remember the great merit of Ki Ageng Gribig, one of the missionaries of Islam in Jatinom Klaten during the reign of the "Sultan Agung Hanyokrokusumo". Yaqowiyu ritual uniqueness lies in deployment "apem" in peak ceremony, which is around cake made of rice flour with coconut pieces in the middle.

This research aims to reveal the meaning of Yaqowiyu. Research methods used are observation, life history interviews and historical method is to do an analysis of the documents.

The results showed that Javanese people is still strong believe in animism. Yaqowiyu interpreted as a ritual to mantain the safety and peace embodied by the behavior of "ngalap berkah". "Apem" cake meant as a tool to realize their request. But on the other hand, Yaqowiyu also be used as a propaganda strategy to spread the religion of Islam. At this point, Yaqowiyu also be interpreted as a tourist commodity that can be sold.
\end{abstract}

\section{PENDAHULUAN}

Islam yang berkembang di Indonesia mula-mula adalah Islam sufi (mistik), yang salah satu ciri khasnya adalah bersifat toleran dan akomodatif terhadap kebudayaan dan kepercayaan setempat, yang dibiarkan eksis sebagaimana semula, hanya kemudian diwarnai dan diisi dengan ajaran-ajaran Islam.

Secara etimologis, sinkretisme berasal dari perkataan syin dan kretiozein atau kerannynai, yang berarti mencampuradukkan elemen-elemen yang saling bertentangan. Adapun pengertiannya adalah suatu gerakan di bidang filsafat dan teologi untuk menghadirkan sikap kompromi pada hal-hal yang agak berbeda dan bertentangan (M. Darori Amin, 2000). Sebelum kedatangan Islam di Jawa, agama Hindu, Budha dan kepercayaan asli yang berdasarkan animisme dan dinamisme telah berakar di kalangan masyarakat. Oleh karena itu, dengan datangnya Islam, terjadi pergumulan antara Islam di satu pihak dengan kepercayaankepercayaan yang ada di pihak lain.

Dalam masalah ini, Drewes telah menelitiulang tiga buah manuskrip lama yang berasal dari abad ke-15 atau ke-16. Ketiga manuskrip tersebut menunjukkan tentang Islam ortodoks yang dapat diterima oleh semua pihak di kalangan umat Islam. Yang kedua adalah mereka yang menerima Islam, tetapi belum dapat melupakan ajaran-ajaran lama. Oleh karena itu mencampuradukkan antara kebudayaan dan ajaran-ajaran Islam dengan kepercayaan-kepercayaan lama.

Sikap toleran dan akomodatif terhadap kepercayaan dan budaya setempat, di satu sisi memang dianggap membawa dampak negatif, yaitu sinkretisasi dan 
pencampuradukkan antara Islam di satu sisi dengan kepercayaan-kepercayaan lama di lain pihak, sehingga sulit dibedakan mana yang benar-benar ajaran Islam dan mana pula yang berasal dari tradisi. Namun aspek positifnya, ajaran-ajaran yang disinkretiskan tersebut telah menjadi jembatan yang memudahkan masyarakat Jawa dalam menerima Islam sebagai agama mereka yang baru. Sebaliknya ajaran-ajaran tersebut memudahkan kalangan-kalangan pesantren untuk mengenal dan memahami pemikiran dan budaya Jawa, sehingga memudahkan mereka dalam mengajarkan dan menyiarkan Islam kepada masyarakat Jawa.

Salah satu sikap dan perilaku sinkretis ini tampak pada prosesi ritual Yaqowiyu. Yaqowiyu adalah upacara adat yang diadakan di Jatinom, sebuah kecamatan di Klaten Jawa Tengah, yang diadakan setiap bulan Sapar. Oleh karena itu, penduduk setempat sering menyebut dengan Saparan. Ritual ini berkembang sejak zaman Mataram Islam, yang diadakan untuk mengenang jasa besar Ki Ageng Gribig, salah satu penyebar agama Islam di jatinom Klaten pada masa Sultan Agung Hanyokrokusumo. Tradisi ini masih tetap lestari hingga kini, bahkan yang menghadiri ritual pada tahun ini diperkirakan lebih dari 25.000 orang atau meningkat dari tahun sebelumnya yang berjumlah 20.000 orang (KlatenOnline). Pengunjung datang dari pelbagai pelosok daerah Jawa seperti Semarang, Demak, Muntilan, Salatiga dan daerah-daerah lain. Ritual Yaqowiyu ini tidak dihilangkan oleh ulama/mubaligh tetapi dibiarkan berlanjut dengan diisi dan diwarnai dengan unsurunsur Islam. Keunikan Saparan adalah penyebaran kue apem pada saat puncak acara, yaitu sebuah kue bundar dari tepung beras dengan potongan kelapa di tengahnya. Disamping itu ada juga ritual-ritual lain yang dilaksanakan yaitu ziarah ke Makam Ki Ageng Gribig dan sendang air Suran.

\section{RUMUSAN MASALAH}

Kajian mengenai tradisi Yaqowiyu yang dilaksanakan di daerah Jatinom Klaten dapat ditemukan dalam buku karya Muh. Fajar Shodiq, (2008) yang berjudul "Akulturasi Budaya Islam dalam Tradisi Saparan/ Yaqowiyu di Jatinom Klaten". Namun buku ini berhenti pada melihat model akulturasinya semata, tidak sampai kepada analisis mengenai simbol-simbol dan makna dalam konteks interaksi yang terjadi diantara komunitas pelaku ritual saparan yaqowiyu. Bila kita lihat praktek ritual Yaqowiyu ini dipenuhi dengan simbol-simbol yang menarik untuk dikaji lebih lanjut, baik dari aspek material yang digunakan dalam ritual ini, maupun aspek makna spiritual dari prosesi ritual hingga benefit yang diharapkan oleh pengunjung pasca-ritual. Oleh karena itu, tulisan ini akan mencoba menjawab kekosongan pembahasan ini, sehingga dapat dirumuskan pertanyaan-pertanyaan sebagai berikut :

1. Bagaimana prosesi ritual Yaqowiyu diadakan sejak tahap awal hingga akhir ritual?

2. Materi apa saja yang digunakan dalam prosesi ritual Yaqowiyu ini?

3. Apa makna simbolik yang terkandung dalam ritual Yaqowiyu ini?

\section{LANDASAN TEORI}

Kebudayaan paling efektif ditelaah secara murni sebagai sistem simbol. Prosesnya adalah dengan memilah-milah unsurnya, mengidentifikasi hubunganhubungan internal diantara unsur-unsur itu dalam bentuk struktur, dan kemudian mencirikan seluruh sistem menurut pusat simbol-simbol yang di sekelilingnya kebudayaan ditata.

Kata simbol berasal dari kata Yunani "symbollein" yang berarti mencocokkan dua kepingan atau kedua bagian yang disebut symbola (Dillistone, 2002). Sebuah simbol pada mulanya adalah sebuah benda, 
sebuah tanda, atau sebuah kata, yang digunakan untuk saling mengenali dan dengan "arti" yang sudah dipahami. Kalau dalam penggunaan semula kata symbollein, dua bagian yang dihubungkan itu terbuat dari zat atau bahan yang sama dan kerapkali merupakan replika yang satu dari yang lain. Namun di kemudian hari, penggunaan komponen primer seringkali sangat berlainan rupanya dan berbeda bahannya dengan apa yang disimbolkan, tetapi dengan suatu cara dapat menggambarkan atau mengingatkan atau menunjuk kepada apa yang disimbolkan tersebut.

Menurut Erwin Goodenough, simbol didefinisikan sebagai 'barang atau pola yang bekerja pada manusia, dan berpengaruh pada manusia, melampaui pengakuan semata-mata tentang apa yang disajikan secara harfiah dalam bentuk yang diberikan itu'. Simbol termasuk dalam kategori bahasa yang bersifat konotatif, yaitu berasosiasi, tidak persis tepat, memungkinkan beragam penafsiran, tetapi memiliki daya kekuatan untuk menggerakkan manusia melalui sentimen sosial. Daya kekuatan simbol terletak pada sifat sentimen sosial dan emotif itu, yang merangsang orang pemangkunya untuk bertindak sesuai dengan ideologi simbol itu dan juga mempertahankannya (Dillistone, 2002).

Simbol menurut Victor Turner adalah sesuatu yang dipandang menurut persetujuan umum sebagai perlambang atau perwakilan atau mengingatkan sesuatu yang lain lantaran memiliki sifat-sifat analogis atau dengan asosiasi secara faktual atau dalam gagasan. Pola struktur simbolik selalu diungkapkan dalam tindakan ritualistik. Simbol-simbol itu berasosiasi dengan kepentingan tertentu, bertujuan akhir, apakah itu secara jelas dirumuskan atau harus diungkap dari tindakan yang dapat diobservasi (Turner dalam Suhardi, 2012). Dalam antropologi, simbolisasi peristiwa dan materi banyak terjadi dalam upacara agama dan semi agama.
Teori yang akan digunakan untuk memaknai simbol-simbol yang ada dalam ritual yaqowiyu adalah teori Interaksionisme simbolik. Teori ini sebenarnya dibawah payung fenomenologi dan perspektif interpretatif. Maurice Natason, seperti dikutip Mulyana (2001) menggunakan istilah fenomenologis sebagai istilah generik untuk merujuk kepada semua pandangan pengetahuan ilmu sosial yang menganggap kesadaran manusia dan makna subyektifnya sebagai fokus untuk memahami tindakan sosial.

Teori Max Weber tentang teori tindakan merupakan landasan atas teori ini. Weber mendefinsikan tindakan sosial sebagai semua perilaku manusia ketika dan sejauh individu memberikan suatu makna subyektif terhadap perilaku tersebut. Baginya, tindakan manusia pada dasarnya bermakna, melibatkan penafsiran, berfikir dan kesengajaan. Konsekuensinya adalah pendekatan ilmu alam menjadi tidak sesuai untuk menelaah perilaku individu yang bermakna sosial, karena pendekatan ilmu alamhanyamempertimbangkangejala-gejala yang nampak, tetapi mengabaikan kekuatankekuatan tersembunyi yang menggerakkan manusia, seperti emosi, gagasan, maksud, motif, perasaan dan sebagainya.

Menurut perspektif ini, individu bersifat aktif, reflektif dan kreatif, menafsirkan, menampilkan perilaku yang rumit dan sulit diramalkan. Paham ini menolak gagasan bahwa individu adalah organisme pasif yang perilakunya ditentukan oleh kekuatankekuatan atau struktur yang ada diluar dirinya. Jadi, interaksilah yang dianggap variable penting yang menentukan perilaku manusia, bukan struktur masyarakat. Struktur sendiri tercipta dan berubah karena interaksi manusia, yakni ketika individuindividu berfikir dan bertindak secara stabil terhadap seperangkat obyek yang sama (Mulyana, 2001).

Dalam pandangan interaksi simbolik, 
sebagaimana ditegaskan Blumer, proses sosial dalam kehidupan sosial dalam kehidupan kelompok lah yang menciptakan dan menegakkan aturan-aturan, bukan aturan-aturan yang menciptakan dan menegakkan kehidupan kelompok. Dalam konteks ini makna dikontruksikan dalam proses interaksi, dan proses tersebut bukanlah suatu medium netral yang memungkinkan kekuatan-kekuatan sosial memainkan perannya, melainkan justru merupakan subtansi yang sebenarnya dari organisasi sosial dan kekuatan sosial interaksi simbolik juga telah mengilhami perspektif lain, seperti "teori penjulukan" (labeling theory) dalam studi tentang penyimpangan perilaku (deviance), perspektif dramaturgis dari Erving Goffman, dan etnometodologi dari Harold Garfinkel. Ketiga pendekatan tersebut dapat dianggap variasi interaksi simbolik

Teori interksionime simbolik pertama kali dirumuskan oleh George Herbert Mead, seorang ahli filsafat sosial, di dalam bukunya yang berjudul Mind, Self and Society. Namun Herbert Blumer-lah yang mempopulerkan istilah interaksionisme simbolik (symbolic interactionism). Teori interaksi simbolik merupakan perspektif, suatu sudut pandang , yang membimbing cara orang melihat kehidupan sosial (Nasikun, 2003).

Lebih lanjut Nasikun menjelaskan inti konsep simbol menunjuk pada "makna" atau meanings. Bagi para interaksionisme simbolik semua hal (obyek, gagasangagasan, keyakinan-keyakinan, orang nilainilai) tidak hanya ada: semua itu ada dalam makna-makna yang mereka miliki atau diberikan kepada mereka. Apa itu makna, bagaimana kehidupan pribadi memberi makna itu dan seterusnya merupakan pertanyaan-pertanyaan penting yang menjadi pergumulan teori interaksionisme simbolik.

Menurut Blumer ada tiga prinsip dasar yang mendasari interaksionime simbolik:

1. Manusia bertindak terhadap sesuatu diatas dasar makna-makna yang dimiliki oleh sesuatu itu baginya.

2. Makna-makna yang dimiliki oleh sesuatu itu diperoleh dari, atau tumbuh dari, interaksi sosial.

3. Makna-makna itu dipahami dan dimodifikasi melalui proses interpretasi yang dilakukan oleh seseorang terhadap sesuatu yang dihadapi.

Singkatnya teori interaksionisme simbolik didasarkan atas primis-primis sebagai berikut: Pertama, individu merespon suatu situasi simbolik. Mereka merespon lingkungan, termasuk obyek fisik dan obyek sosial (perilaku manusia) berdasarkan makna yang dikandung komponenkomponen lingkungan tersebut bagi mereka. Kedua, makna adalah produk interaksi sosial, karena itu makna tidak melekat pada obyek, melainkan dinegosiasikan melalui penggunaan bahasa. Ketiga, makna yang dipresentasikan individu dapat berubah dari waktu ke waktu, sejalan dengan perubahan situasi yang ditemukan dalam interaksi sosial (Mulyana, 2001 : 71-73).

Jadi menurut interaksi simbolik, perilaku manusia tidak deterministik, sebagaimana yang dianut kaum positivistik. Perilaku adalah produk penafsiran individu atas obyek sekitarnya. Makna yang diberikan pada obyek berasal dari interakasi sosial dan dapat berubah selama interaksi itu berlangsung

\section{METODE PENELITIAN}

Sebagai bagian dalam tradisi penelitian kualitatif pendekatan interaksionisme simbolik membutuhkan pendekatan tertentu. Menurut Denzin ada tujuh prinsip metodologis berdasarkan teori interaksi simbolik:

1. Simbol dan interaksi harus dipadukan sebelum penelitian tuntas.

2. Peneliti harus mengambil perspektif atau peran orang lain yang bertindak 
(the acting other) dan memandang dunia dari sudut pandang subyek; namun dalam berbuat demikian peneliti harus membedakan antara konsepsi realitas kehidupan sehari-hari dengan konsepsi realitas mengenai realitas tersebut.

3. Peneliti harus mengkaitkan simbol dan definisi subyek dengan hubungan sosial dan kelompok-kelompok yang memberikan konsepsi demikian.

4. Setting perilaku dalam interaksi tersebut dan pengamatan ilmiah harus dicatat.

5. Metode peneltian harus mampu mencerminkan proses atau perubahan, juga bentuk perilaku yang statis.

6. Pelaksanaan penelitian paling baik dipandang sebagai suatu tindakan interaksi simbolik.

7. Penggunaan konsep yang layak adalah perrtama-tama mengalahkan (sensitizing) dan kemudian operasional; teori yang layak menjadi teori formal, bukan teori agung (grand theory) atau teori menengah (middle-range theory); dan proposes yang dibangun menjadi interaksional dan universal (Mulyana, 2001).

Menurut Denzin interaksi simbolik mengedepankan pengamatan peran serta, wawancara sejarah hidup, dan metode historis (analisis dokumen) peran sangat krusial. Karena metode ini memungkinkan peneliti memadukan simbol dan interaksi, mengambil peran pihak yang diamati, mengaitkan dunia simbol dengan dengan dunia sosial, merekam situasi yang berlaku, mengemukakan perubahan dan proses dan membuat prinsip-prinsip yang lebih terarah. (Mulyana, 2001)

\section{HASIL PENELITIAN DAN PEMBAHASAN}

\section{Sejarah Upacara Saparan/Yaqowiyu}

Tradisi Saparan dilakukan oleh masyarakat Mataram sejak masyarakat
Mataram mengikuti penanggalan Jawa. Sebelum 1633 Masehi, masyarakat Jawa menggunakan kalender berdasar pergerakan matahari (masehi). Sultan Agung Hanyokrokusumo, Raja Mataram, mengubah sistem penanggalan itu dari matahari ke bulan. Dengan demikian, seluruh Jawa dan Madura, kecuali Banten, mengikuti penanggalan itu. Bulan Suro sebagai awal tahun Jawa juga disebut bulan yang sakral, karena dianggap bulan yang suci. Di bulan ini banyak orang melakukan perenungan, bertafakur, berintrospeksi, mendekatkan diri kepada sang Khalik. Bulan Suro atau Muharam ini juga diyakini masyarakat Jawa sebagai bulan gawat atau keramat. Tak aneh bila pada bulan Suro banyak ritual dilakukan, termasuk jamasan pusaka keraton. Di bulan kedua, Sapar atau Syafar, masyarakat bergembira, mengucap syukur dengan pelbagai upacara saparan. Salah satu bentuk ritual saparan yang menarik adalah Saparan Ya Qowiyu di Klaten.

Dalam perspektif kesejarahan, upacara ini pertama kali berbentuk majelis pengajian yang dikunjungi oleh umat Islam dan masyarakat sekeliling Jatinom. Menurut sesepuh masyarakat Jatinom, Sri Harjoko bahwa saparan Ya Qowiyu merupakan upacara ritual yang dilakukan oleh masyarakat Jatinom untuk mengingat cikal bakal Jatinom yaitu Ki Ageng Gribiq yang merupakan tokoh penyebar agama Islam. Ritual ini diawali dari suatu peristiwa pembagian kue apem oleh Ki Ageng Gribig pada 15 Sapar $1511 \mathrm{H}$, pada waktu itu Ki Ageng Gribiq baru saja pulang dari tanah suci Makkah setelah menunaikan rukun Islam yang kelima dan membawa oleh-oleh roti dan segumpal tanah liat dari Arofah. Beliau Sunan Gribig pulang dengan membawa oleh-oleh berupa tiga buah roti gimbal yang masih hangat, untuk dibagi-bagikan kepada tetangga dan sanak saudara yang ada. Mereka berkumpul untuk mendengar cerita dan wejangan ilmu dari beliau, namun sebelum mereka pulang oleh beliau dibagikan oleh- 
oleh tadi secara merata, akan tetapi oleh-oleh tadi ternyata tidak mencukupi untuk semua yang hadir, oleh karena itu beliau menyuruh istrinya, Nyai Ageng, untuk memasak kue tadi menjadi lebih banyak agar semua yang hadir mendapat oleh-oleh (Shodiq, 2008 : 24).

Upacara ini dinamakan Yaqowiyu diambil dari doa Kyai Ageng Gribig sebagai penutup pengajian yang berbunyi : $Y a$ Qowiyu Yaa Aziz Qowina wal Muslimin yang artinya : Ya Tuhan, dzat yang maha kuat, ya Allah dzat yang maha menang, mudahmudahan memberikan kekuatan kepada kami dan kaum muslimin. Doa Kyai Ageng Gribig itu dibacakan dihadapan hadirin, para pengunjung kemudian menyebutkan Majelis Pengajian itu dengan sebutan nama : ONGKOWIYU yang dimaksudkan JONGKO WAHYU atau mencari wahyu. Kemudian oleh anak turunnya istilah ini dikembalikan pada aslinya yaitu YA QOWIYU. Upacara ini diselenggarakan setiap satu tahun sekali pada hari Jumat pertengahan bulan Sapar (http://indonesia-life.com/kolom).

Berangkat dari kharisma KyaiAgeng dan kejadian itu, maka tradisi yang spontan itu menjadi tradisi yang dianggap "bermakna" sehingga "makna" yang ada memberi arti dan kesan dalam sanubari masyarakat setempat. Oleh karena itu, tradisi saparan yaqowiyu masih terus dilestarikan hingga sekarang, bahkan bagi masyarakat Jatinom itu sudah merupakan satu keharusan yang tidak bisa ditinggalkan. Ritual ini dilaksanakan tiap bulan Safar antara tanggal 12-18 (Shodiq, 2008).

Pada masa sekarang, untuk memperlancar jalanya upacara perayaan ini, telah dibentuklah panitia gabungan, yaitu panitia yang terdiri dari tokoh masyarakat dan sesepuh upacara dengan para pejabat pemerintah setempat.

\section{Unsur-unsur ritual Ya Qowiyu}

Upacara Keagamaan adalah salah satu bentuk pengungkapan dari pengalaman keagamaan yang tak dapat dipisahkan dari bentuk-bentuk pengungkapan lainya. Dalam upacara itu merupakan reaksi manusia terhadap "realitas mutlak" yang dihadirkan manusia saat ia mendekatkan diri kepada-Nya, sehingga upacara keagamaan mempunyai komponen-komponen yang menyusunnya. Diantara komponen upacara itu adalah, waktu, tempat, tokoh, doa dan alat-alat upacara yaitu :

\section{a. Waktu Upacara}

Dalam setiap upacara, terdapat waktu yang dianggapnya suci dan dipandang lebih cocok dibandingkan dengan waktu yang lain. Pada waktu yang dianggap istimewa, Sang Pencipta membuka peluang untuk menebarkan rahmat dan kasih sayangnya. Upacara Yaqowiyu dilaksanakan tiap bulan Safar antara tanggal 12 sampai 18 pada tiap tahunnya, hari yang menjadi patokan adalah hari jumat, hari yang dianggap suci bagi umat Islam. Pada malam hari menjelang upacara puncak dilaksanakan, para sesepuh upacara berada di tanah lapang guna melihat semacam teja yang datang dari arah barat, teja yang dimaksud adalah seberkas sinar yang diyakini sebagai kue apem yang berwarna putih yang dikirim Tuhan dari Mekah. Datangnya teja tersebut oleh para sesepuh upacara dikatakan sebagai suatu kepastian, artinya menjelang upacara puncak, teja itu pasti datang.

\section{b. Tempat Upacara Yaqowiyu}

Dalam ritual selalu ada tempat khusus yang dimaksudkan adalah tempat dimana makhluk supranatural biasanya berdiam diri dan bersemayam, sehingga tempat-tempat itu diperlukan secara istimewa pada waktu upacara dilaksanakan, tempat itu dapat berupa gua, tempat suci atau sebidang tanah, ditempat itu di kunjungi sesuai dengan keinginan para peziarah. Dalam ritual ini terdapat tempat-tempat yang menjadi tujuan untuk menyampaikan maksud dan keinginan pengunjung yang merupakan 
suatu rangkaian yang harus dilakukan dan dikunjungi, tempat itu antara lain ;

\section{c. Makam Ki Ageng Gribig}

Makam ini terletak di belakang Masjid Besar Jatinom, makam ini berupa batu nisan yang diselimuti dengan kain putih. Untuk sampai ke makam ini peziarah harus melewati tiga buah pintu, pintu pertama adalah pintu ke makam secara umum, pintu kedua adalah pintu memasuki cungkup dan pintu ketiga pintu menuju makam. Berziarah ke makam ini merupakan awal dari prosesi memohon petunjuk dan mencari berkah dari upacara ini, sehingga dalam acara ini terdapat banyak orang yang antri. Dalam melaksnakan ziarah berbagai permohonan disampaikan antara lain memohon diberi keselamatan, dimudahkan rizqi, naik pangkat, meminta jodoh dan sebagainya.

\section{d. Sendang Air Suran}

Mata air yang dimaksud adalah sebuah sumur kecil yang terletak di pinggir sungai, di sebelah timur makam Ki Ageng Gribig. Di sebelah sumber ini terdapat mushola kecil yang dipergunakan sembahyang oleh peziarah sebelum menyampaikan maksud untuk mengambil air. Menurut keyakinan peziarah air ini dapat memberi manfaat yang banyak, diantaranya untuk pengobatan, jimat dan lain-lain.

\section{e. Oro-oro Tarwiyah}

Oro-oro atau alun-alun tarwiyah ini terletak di dusun Krajan, sebelah barat Jatinom berjarak kurang lebih $500 \mathrm{~m}$, tempat ini berukuran $35 \times 12$ meter dan digunakan untuk sholat ied pada waktu itu dengan imam Ki Ageng Gribig sendiri. Oro-oro tarwiyah ini adalah sebidang tanah yang digunakan untuk menanam segenggam tanah dari Makkah yang dibawa Ki Ageng Gribig waktu melaksanakan ibadah haji. Maksudnya adalah untuk mengingat-ingat keadaan di Makah waktu itu."Dene siti saking oro-oro ngarofah
(Arofah) wau puningko kangge pengengetenget kawontenan ing negri Mekah, lajeng katanem wonten pengimamanipun oro-oro, ingkang kanameaken Oro-oro Tarwiyah".. Ditempat ini pula banyak dikunjungi oleh peziarah yang datang dan bahkan bermalam hingga menjelang upacara penyebaran apem dilaksanakan.

\section{f. Pemimpin Upacara Yaqowiyu}

Pemimpin dalam upacara yaqowiyu memegang peranan yang sangat penting, ia akan memberi warna dan memberi arah terhadap jalannya upacara. Kedudukan pemimpin dalam upacara secara hierakhis diakui oleh masyarakat sebagai seseorang yang mempunyai kedudukan yang istimewa dan kharismatik, dengan kharisma itu seorang pemimpin dianggap mempunyai kekhususan dan anugrah dari yang maha kuasa. Kharisma didapat oleh seseorang atas dasar hubungan yang tetap dan kedekatannya dengan Tuhan. Dalam upacara ini, tokoh yang berkharisma dan disegani oleh masyarakat setempat sekaligus sebagai tokoh upacara ini adalah Ki Ageng Gribig. Beliau sebagai ulama yang dikenal sebagai pembawa Islam di Jatinom. Kharisma beliau sampai sekarang masih ada dan menurun kepada keturunan beliau yang masih ada hingga sekarang ini yaitu mbah Wignyo 75 tahun. Pengaruh kharisma yang dimiliki oleh mbah Wignyo masih tetap diakui oleh peziarah upacara yaqowiyu, mereka menganggap bahwa kharisma yang dimiliki oleh Ki Ageng Gribiq tetap menurun padanya.

\section{Alat-alat Upacara Yaqowiyu}

Dalam upacara Saparan/Yaqowiyu terdapat alat-alat upacara yang merupakan simbol untuk mendekatkan diri dengan Tuhan melalui wasilah dengan kekuatan yang ada di dalam upacara ini, alat-alat itu antara lain;

\section{a. Kue Apem}

Kue apem ini terbuat dari tepung 
beras yang diberi gula pasir dan santan, selanjutnya dimasak dengan menggunakan cetakan bulat-bulat, kue ini merupakan simbol utama yang digunakan dalam upacara ini, yakni simbol-simbol yang digunakan untuk merealisasikan tujuan yang dimohonkan, artinya setelahpengunjung menyampaikan maksud ditempat upacara, maka kue ini sebagai alat untuk mewujudkan permintaan tadi, para pengunjung berusaha mendapatkan kue apem ini dalam jumlah yang sebanyakbanyaknya.

\section{b. Bunga}

Dalam upacara ini bunga digunakan oleh sesepuh upacara sebagai mantra pada kue apem yang akan disebarkan kepada pengunjung. Sedangkan pengunjung upacara menggunakan bunga ini sebagai sesaji dalam memanjatkan permohonan agar dapat menghadirkan kekuatan dalam upacara ini, sehingga permohonannya dikabulkan dan mendapat berkah. Dalam upacara ini bunga yang digunakan adalah bunga mawar, kanthil, kenanga, melur dan melati. Bungabunga tersebut diletakkan dalam baskom kecil yang diberi air secukupnya kemudian air tersebut dipercikkan ke dalam kue apem.

\section{c. Kemenyan}

Kemenyan ini merupakan pasangan bunga dalam melakukan sesaji, pada upacara saparan/ yaqowiyu kemenyan ini diperuntukkan untuk mempercepat sampainya permohonan pada dewa atau leluhur yang berada di alam ghaib. Dengan kemenyan diharap bahwa pengunjung telah mensucikan diri dari noda dan dosa yang dibenci oleh para dewa dan leluhur, sehingga dengan kesucian jiwa ini permohonan mereka dapat terkabul.

\section{d. Bacaan Doa Dalam Upacara Yaqowiyu}

Sedangkan lafal doa tersebut adalah;

$$
\begin{aligned}
& \text { ـ نيجلسملاو انوق .زيزع اي بيوق اي } \\
& \text { نينجؤملاو انقزراو قآزر اي يوق اي اي }
\end{aligned}
$$

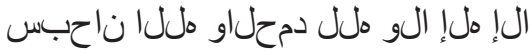

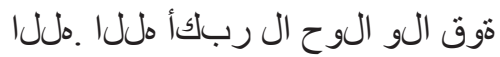

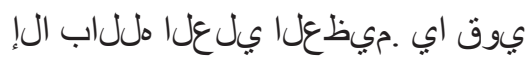

$$
\begin{aligned}
& \text { اي يوق اي ـ نيملسجلاو انوق زيزعاي } \\
& \text { ملا ءاشام .نينجؤملاو انقزراو قازي }
\end{aligned}
$$

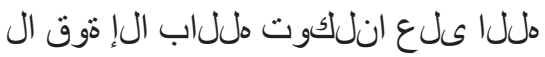

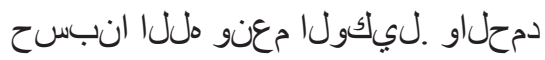

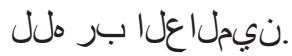

Artinya "Ya Tuhan, dzatyang maha kuat, ya Allah dzat yang maha menang, mudahmudahan memberikan kekuatan kepada kami dan kaum muslimin, ya Allah yang maha kuat, ya Allah dzat yang memberi rizqi, mudah-mudahan memberi rizqi kepada kami dan kaum muslimin, maha suci Allah dan segala pujian milik Allah, tidak ada Tuhan yang berhak disembah kecuali Allah. Allah maha besar tiada daya kekuatan kecuali atas pertolongan Allah yang maha luhur dan maha agung. Ya Allah dzat yang maha kuat, ya Allah dzat yang maha menang, mudahmudahan memberikan kekuatan kepada kami dan kaum muslimin, ya Allah dzat yang maha kuat, ya Allah yang memberi rizqi, mudah-mudahan memberi rizqi kepada kami dan kaum muslimin, segala yang dikehendaki Allah pasti terjadi, tidak ada daya kekuatan kecuali atas pertolongan Allah, kami menyerahkan diri pada Allah, Allah mencukupi semua kebutuhan kami, segala pujian hanya kepada Allah yang merajai seluruh alam."

\section{Gambaran Prosesi Upacara Ya Qowiyu pada Masa Sekarang}

Ritual Ya Qowiyu di Jatinom Klaten merupakan salah upacara penting dalam siklus tahunan yang dilaksanakan oleh masyarakat Jatinom, sehingga ritual ini dipersiapkan dengan matang oleh sesepuh desa, tokoh masyarakat dan Pemda Klaten. Persiapan ini meliputi alat ritual seperti bunga, kemenyan, kue apem dan kesiapan 
teknis pelaksanaannya seperti kebersihan makam dan sendang air Suran, pembangunan oro-oro Tarwiyah, tenda dan kursi untuk tamu utama dan lainnya.

Oleh karena itu, untuk memperlancar jalannya upacara saparan Ya Qowiyu ini, langkah pertama yang dilakukan adalah membentuk panitia gabungan, yaitu panitia yang terdiri dari tokoh masyarakat dan sesepuh upacara dengan para pejabat pemerintah setempat. Panitia dari sesepuh dan tokoh masyarakat bertugas untuk mengatur prosesi upacara ritual hingga pelaksanaan upacara penyebaran apem dan menyiapkan segala keperluan untuk melayani pengunjung. Sedangkan panitia yang dibentuk oleh aparat pemerintah bertugas untuk menjaga keamanan dan ketertiban jalannya upacara. Dengan jumlah pengunjung lebih dari 25.000 orang (dua puluh lima ribu orang), maka pelibatan MUSPIDA khususnya aparat kepolisian dan KODIM menjadi satu keharusan untuk menjaga kelancaran dan keamanan jalannya upacara ritual Ya Qowiyu ini.

Setelah dibentuk panitia, maka panitia dari sesepuh upacara akan menentukan tanggal pelaksanaan dari upacara ritual Ya Qowiyu ini. Upacara Ya Qowiyu dilaksanakan setiap bulan Safar antara tanggal 12 sampai 18 pada tiap tahunnya, hari yang menjadi patokan adalah hari Jumat, hari yang dianggap suci bagi umat Islam. Cara untuk menentukan tanggal pelaksanaan ritual dengan patokan sebagai berikut :

\begin{tabular}{|l|c|l|c|}
\hline Tahun Jawa & Bulan & \multicolumn{1}{|c|}{ H a r i } & Tanggal \\
\hline Alip & Sapar & Jum`at Pon & 15 \\
Ehe & Sapar & Jum`at Kliwon & 18 \\
Jimawal & Sapar & Jum`at Kliwon & 13 \\
Je & Sapar & Jum`at Pahing & 16 \\
Dal & Sapar & Jum`at Pahing & 12 \\
Be & Sapar & Jum`at Wage & 14 \\
Wawu & Sapar & Jum`at Legi & 17 \\
Jumakir & Sapar & Jum`at Legi & 13 \\
\hline
\end{tabular}

Setelah hari ditentukan, maka pada awal bulan Safar masyarakat Jatinom mulai mengadakan gotong royong untuk membersihkan tempat yang akan digunakan untuk upacara. Tempat inti yang dibersihkan dan dihias diantaranya adalah Masjid Besar Jatinom, Makam Ki Ageng Gribig, Sendang Air Suran, Mushola samping sendang, Lapangan Jatinom untuk upacara penyebaran kue Apem dan lainnya.

Prosesi upacara dimulai hari kamis dimana panitia inti mulai sibuk mengatur dan menerima sumbangan kue apem dari masyarakat, penyerahan kue apem ini dilaksanakan ditempat yang nantinya akan digunakan sebagai tempat penyebaran kue

apem, yaitu disebuah panggung dengan ukuran tinggi lima meter dan lebar tiga meter yang terletak di sebelah selatan Masjid Besar Jatinom. Pada saat warga masyarakat menyerahkan kue apem ini, panitia akan memberi ganti dengan kue apem serupa yang dibuat oleh panitia sebagai bentuk ucapan terimakasih atas sedekah yang diberikan. Kue apem dari panitia ini menurut anggapan masyarakat adalah kue yang mengandung berkah, kue ini diberikan dalam jumlah yang telah ditentukan, yakni tiap sepuluh kue apem yang disumbangkan masyarakat akan diganti dengan sebuah kue apem dari panitia, kue dari panitia ini diyakini mampu memberikan sesuatu yang diinginkan oleh yang memohonnya. Kesibukan panitia 
untuk menerima apem ini terus berlangsung hingga waktu menjelang acara penyebaran apem dimulai yakni setelah sholat Jumat di Masjid Besar Jatinom. Disamping itu, panitia kasepuhan juga membuat kue apem yang dibuat dalam bentuk gunungan lanang yang dikenal dengan nama Ki Kiyat dan gunungan wadon yang dikenal dengan nama Nyi Kiyat.

Rangkaian ritual diawali pada hari Kamis dengan mengarak gunungan apem Ki Kiyat dan Nyi Kiyat dari halaman Kantor Kecamatan Jatinom, dengan rute jalan protokol menuju Masjid Alit hingga Masjid Gedhe Jatinom yang menjadi tempat dimakamkannya Ki Ageng Gribig. Rombongan terdiri atas para sesepuh, tokoh masyarakat, pejabat Pemkab Klaten yang terdiri atas perwakilan dari Satuan Kerja Perangkat Daerah (SKPD) serta sejumlah camat yang semuanya berpakaian adat Jawa. Sebelum sampai di Masjid Gedhe, kedua gunungan apem mampir sebentar di Masjid Alit. Di masjid ini, rombongan disambut sesepuh masjid Alit. Di masjid ini pula, dibacakan doa yang dipimpin langsung Ketua sesepuh Masjid Alit. Dalam doanya, sesepuh masjid Alit berharap agar Kirab Gunungan Apem ini membawa berkah bagi semua warga di Jatinom Klaten. Selesai dibacakan doa, Gunungan apem dibawa ke Masjid Gedhe. Dimasjid ini Gunungan Apem diserahkan kepada keturunan $\mathrm{Ki}$ Ageng Gribig. Di masjid inilah, dua buah gunungan itu diistitirahatkan selama semalam. Selanjutnya pada malam jum'at di Masjid Gedhe diadakan acara tahlilan dan tabligh akbar serta pembacaan singkat tentang sejarah perjuangan Ki Ageng Gribig.

Pada malam sekitar tengah malam, para sesepuh upacara berada di tanah lapang guna melihat semacam teja yang datang dari arah barat, teja yang dimaksud adalah seberkas sinar yang diyakini sebagai kue apem yang berwarna putih yang dikirim Tuhan dari Mekah, Saudi Arabia. Datangnya teja tersebut oleh para sesepuh upacara dikatakan sebagai suatu kepastian, artinya menjelang upacara puncak, teja itu pasti datang.

Puncak acara dimulai dengan shalat Jumat bersama di Masjid Gedhe. Selesai Jumatan, gunungan lanang, dikenal dengan nama Ki Kiyat, dan gunungan wadon, dikenal dengan nama Nyi Kiyat, yang telah disemayamkan semalam di dekat masjid, diarak menurunitangga masjid Gedhemenuju panggung di lapangan Sendang Plampeyan (tanah lapang di pinggir Kali Soka, di selatan masjid dan makam Ki Ageng Gribig). Arakarakan terdiri dari peraga Ki Ageng Gribig, Muspida Klaten, Dua Gunungan, Putri Domas, dan Para Pengawal. Kemudian peraga Ki Ageng Gribig akan memimpin doa bersama. Selanjutnya, dia menyerahkan apem yang ditempatkan dalam panjang ilang (keranjang terbuat dari janur) kepada Bupati Klaten. Bupati akan mengawali upacara penyebaran dengan melempar apem dalam panjang ilang kepada pengunjung. Kemudian, petugas penyebar yang berada di dua menara "oro-oro tarwiyah" segera mengikutinya dengan melemparkan ribuan apem. Ribuan pengunjung pun tanpa dikomando berebut apem, bahkan sampai terinjak kakinya atau bertabrakan gara-gara ingin saling menangkap apem. Dalam waktu singkat sekitar empat ton apem sumbangan dari para warga sekitar habis tak tersisa. Upacara penyebaran apem ini memakan waktu cukup lama antara 1-2 jam. Dengan selesai penyebaran apem ini, selesai sudah seluruh rangkaian prosesi upacara ritual Ya Qowiyu.

\section{Makna Tradisi Ya Qowiyu}

Untuk mengungkap makna tradisi ritual Ya Qowiyu di Jatinom ini tentu tidak bisa dilepaskan dari konteks kebudayaan yang melingkupinya yaitu kebudayaan Jawa khususnya. Oleh karena itu, setelah melakukan pembacaan berulang-ulang terhadap tradisi ini dan dikomparasikan dengan kebudayaan Jawa khususnya sistem kepercayaan dan ritual agama jawi, maka 
penulis menemukan beberapa makna tafsiran yang bisa dipetik dari ritual Ya Qowiyu di Jatinom ini, yaitu :

\section{a. Makna Apem yang ada dalam ritual Ya Qowiyu}

Apem dalam upacara Yaqowiyu merupakan simboldominan yang mempunyai tiga sifat sebagaimana disebutkan oleh Victor Turner. Penyebaran apem berasosiasi dengan gagasan untuk memohon ampun kepada Sang Pencipta dan permohonan keberkahan dari Sang Pencipta.

Makna esoterik apem dalam ritual Yaqowiyu dapat kita lihat dari penafsiranpenafsiran berikut. Menurut Panji Supardi, juru kunci Makam Kiai Ageng Gribig di Jatinom, bahwa kue apem yang dibagikan kepada para santrinya oleh Kiai Ageng Gribig memiliki makna khusus. Menurutnya, kue apem sebetulnya dalam arti lain, agar manusia diberikan ampunan oleh Tuhan Yang Maha Esa. Apem bisa dirujukan secara etimologis ke bahasa Arab afwun yang berarti ampunan. Jadi jika masyarakat mendapatkan kue apem, maka mereka akan diberikan ampunan segala kesalahannya oleh Tuhan.

Menurut kepercayaan masyarakat Jatinom dan sekitarnya, kue apem baik yang berada dalam gunungan maupun yang disimpan di oro-oro tarwiyah mempunyai kekuatan supranatural yang membawa kesejahteraan bagi yang berhasil mendapatkannya. Kue apem ini bisa menjadi tumbal, tolak bala, atau syarat untuk berbagai tujuan. Bagi petani, bisa untuk tumbal sawah agar tanaman selamat dari segala bencana dan hama penyakit. Bahkan, ada yang percaya siapa yang mendapat banyak apem pada perebutan itu merupakan tanda akan memperoleh rezeki melimpah. Contohnya adalah Harjo, 54 tahun, pengunjung asal Temanggung yang mampu mengumpulkan delapan apem ia mengatakan bahwa "Apem ini penolak bala dan bisa mendatangkan rezeki. Anak saya tiga. Sisanya akan saya tanam di sawah".

Disamping itu juga ada apem yang dibuat menjadi gunungan yang berbentuk gunungan lanang yang dikenal dengan nama Ki Kiyat, dan gunungan wadon yang dikenal dengan nama Nyi Kiyat. Makna sensori tercermin dari struktur gunungan yang penataannya disusun menurun seperti sate. Apem disusun dengan urutan 4-2-4-4-3 yang mempunyai makna sama dengan jumlah raka'at sholat yaitu sholat isya/subuh/dhuhur/ashar dan maghrib. Makna gunungan dengan merujuk ke Irwan Abdullah (2002 : 66-70) bisa ditarik kedalam tiga makna yaitu pertama, gunung diasosiasikan sebagai suatu tempat yang tinggi letaknya. Sesuatu yang letaknya tinggi dianggap suci karena dihubungkan dengan langit dan Tuhan. Zaman dulu dikenal kayangan yang menjadi tempat para dewa dan kerajaan-kerajaan juga dibuat di gunung-gunung. Gunungan dihubungkan dengan konsep gunung yang sesungguhnya yang berati mulia dan kesucian. Kedua, Gunungan kakung "ki niyat" dihubungkan dengan phallus (alat vital laki-laki) yang mengacu pada nilai-nilai kehidupan, yakni asal-muasal kehidupan manusia. Selain itu gunungan kakung juga memiliki gambaran tentang dunia seisinya yang tercakup berbagai unsur didalamnya, seperti bumi, angkasa atau langit, api, angin, tumbuh-tumbuhan, dan manusia itu sendiri dengan berbagai sifatnya. Manusia yang digambarkan di sini adalah ksatrio utomo yang merupakan figur ideal bagi orang Jawa yang memiliki sifatsifat mulia. Ketiga, Gunungan Wadon "nyi kiyat" dihubungkan dengan konsep induk yakni sifat seorang ibu yang mengatur, mendidik dan mengayomi anak, oleh karena itu gunungan wadon dihubungkan supaya manusia bisa mengayomi alam, mengatur dan mendidik alam supaya keseimbangan hidup bisa terwujud, baik di jagad gedhe maupun jagad cilik.

\section{b. Makna Oro-Oro Tarwiyah}

Oro-oro tarwiyah ini terletak di dusun 
Krajan, sebelah barat Jatinom berjarak kurang lebih $500 \mathrm{~m}$, tempat ini berukuran 35 X 12 meter dan digunakan untuk sholat ied pada waktu itu dengan imam KiAgeng Gribig sendiri. Oro-oro tarwiyah ini adalah sebidang tanah yang digunakan untuk menanam segenggam tanah dari Makkah yang dibawa Ki Ageng Gribig waktu melaksanakan ibadah haji. Maksudnya adalah untuk mengingat-ingat keadaan di Makah waktu itu."Dene siti saking oro-oro ngarofah (Arofah) wau puningko kangge pengengetenget kawontenan ing negri Mekah, lajeng katanem wonten pengimamanipun oro-oro, ingkang kanameaken Oro-oro Tarwiyah".

Tarwiyah secara bahasa berasal dari bahasa arab yang berarti mempetimbangkan segalaaspek. Darisini,parapengunjungdiajak untuk memikirkan dan mempertimbangkan dengan matang jalan hidup atau lelaku yang akan dijalani. Disini ditanam tanah yang berasal dari oro-oro arofah Mekah artinya setelah orang mempertimbangkan dengan matang (tarwiyah) maka ia akan mendapatkan arofah (ilmu pengetahuan) yang ditanam didalam dadanya. Pada mulanya hanya ilmu tertentu, kemudian berkembang semakin kompleks sehingga bisa memecahkan berbagai problematika yang dihadapi oleh manusia. Jika ia sudah memiliki banyak ilmu yang menancap di dada, maka ia akan semakin dekat dengan tujuannya yaitu mencapai titik nirwana. Pada tahap ini manusia sudah bisa membedakan mana yang baik dan mana yang buruk. Manusia seperti ini sudah mampu menahan gejala hawa nafsu, memiliki tindakan yang wajar bersahaja, dan memiliki kebiasaan sehari-hari yang serba tertib.

\section{c. Ya Qowiyu bermakna peng-hormatan terhadap arwah leluhur}

Agama Jawi mengenal banyak sekali tokoh-tokoh keramat, baik itu tokohtokoh historis maupun tokoh yang dikenal melalui kesusasteraan babad. Sebagai bentuk penghormatan terhadap tokoh-tokoh dari leluhur mereka, orang-orang Jawa mengadakan suatu upacara keagamaan. Tradisi Saparan merupakan salah satu bentuk penghormatan terhadap arwah leluhur mereka yaitu Ki Ageng Gribig sekaligus sebagai wahana untuk mengingat jasa-jasa leluhur mereka yang besar.

Dalam agama Jawi arwah leluhur yang telah menetap di makam (pasareyan) leluhur, para keturunan dan pengikutnya akan tetap memuja dan memanggil arwah leluhur itu untuk dimintai nasehat tentang persoalan rohaniah maupun material. Pada tradisi Saparan sering terlihat adanya permohonan sesuatu terhadap arwah leluhur yang disertai dengan pemberian sesaji. Pada tradisi Saparan/ Yaqowiyu makam ki ageng Gribig senantiasa dipenuhi oleh peziarah, mereka berziarah sambil menaburi bunga yang diiringi dengan pembacaan do`a sambil membakar dupa. Selain itu mereka juga memohon doa restu kepada arwah, terutama bila seseorang tersebut menghadapi tugas berat, atau keinginan memperoleh suatu hal.

Jadi pada dasarnya, tradisi Saparan yang masih dilaksanakan di kalangan orang Jawa merupakan suatu bentuk upacara untuk menghormati arwah leluhur mereka (Ki Ageng Gribig). Dalam konsep agama Jawi tradisi Saparan dipandang sebagai suatu aktivitas upacara yang penting dan masih diyakini sebagai sarana hubungan komunikasi batin antara arwah leluhur dengan orang yang masih hidup.

\section{d. Ya Qowiyu sebagai komuni-kasi mistis dengan tokoh keramat untuk ngalap berkah dan meningkatkan tingkat spiritual.}

Dalam tradisi Saparan atau Yaqowiyu mengandung nilai-nilai keselamatan dan kedamaian, Saparan ini memiliki nilai keseimbangan dan keselarasan antara makrokosmos dengan mikrokosmos, antara "jagad gede" dengan "jagad cilik" dalam mewujudkan keselamatan, keseimbangan dan keselarasan tersebut diwujudkan dalam 
bentuk tata cara "kosmis relegius magis" yang dalam hal ini diwujudkan dalam tradisi Saparan atau Yaqowiyu, yang inti maknanya adalah keselamatan dan ketentraman.

Saparan merupakan kepercayaan sebagaian besar masyarakat jawa untuk keselamatan atau dengan istilah "ngalap berkah", hal ini merupakan perpaduan atau campuran antara kepercayaan jawa asli, Hindu dan Islam. Perpaduan itu disebut dengan Sinkretisme. Animisme dipadu dengan unsur kebatinan menjadi Agama Jawa, kemudian Hindu dan Islam dipadu ke dalam Agama Jawa, yang sering disebut dengan Kepercayaan Jawa.

\section{e. Saparan sebagai strategi dakwah berbasis local wisdom}

Para sarjana menyatakan bahwa keberhasilan luar biasa para sufi dalam proses Islamisasi kepulauan Indonesia terutama disebabkan oleh penafsiran mereka mengenai Islam sufi yang sangat cocok dengan latar belakang mistik Hindu Budha dan mistisisme Islam yang menyiapkan lahan subur bagi masyarakat di wilayah itu untuk menerima Islam dengan pola-pola adat dan kepercayaan lokal.

Pola-pola inilah yang dikembangkan di Jawa oleh para Wali Songo dengan menggunakan berbagai cara dakwah yang disesuaikan dengan kebudayaan asli masyarakat Jawa yang dipengaruhi oleh kebudayaan Hindu Budha. Upacara ritual Ya Qowiyu yang pelaksanaannya tidak bisa lepas dari adat istiadat Jawa model Islam Kraton Mataraman dengan Islam, bisa dipandang sebagai strategi dakwah dengan memadukan antara ajaran Islam dengan kebudayaan asli masyarakat Jawa.

\section{F. Upacara Ya Qowiyu bermakna ekonomi, bisnis dan wisata}

Banyaknya pengunjung dalam upacara tradisi Saparan membuat tempat tersebut menjadi ramai, ini berarti kegiatan itu bernilai tambah bagi masyarakat sekitar secara langsung maupun tidak langsung, hal ini mendorong masyarakat di sekitar untuk bermitra usaha yakni dengan berdagang, membuka warung makan/minum maupun berbagai macam dagangan yang diperjualbelikan.

Selain itu warga yang kebetulan mempunyai pekarangan rumah yang luas dan berdekatan dengan tempat upacara, banyak yang menyewakan tempat serta peralatan listrik untuk keperluan membuka warung jajanan mupun cenderamata, begitu pula adanya jasa parkir kendaraan, sedikit banyak membantu meningkatkan kesejahteraan masyarakat sekitar. Dari tahun ke tahun, makna tradisi ini berubah, diantaranya akhir-akhir ini unsur komersial ekonomibisnis mulai muncul. Sekeliling masjid menjadi pasar tiban. Rumah warga dijadikan tempat parkir. Pedagang apem di manamana. Bagi yang tidak membuat apem, bisa membeli. Dari fenomena ini makna apem tidak lagi terkait dengan realitas spiritual tetapi bergeser menjadi makna ekonomi karena apem bisa menjadi icon Jatinom. Sebagaimana diungkap oleh camat Jatinom, Joko Purwanto, yang mengharapkan Jatinom akan lebih terkenal sebagai sentra kue apem karena tradisi Yaqowiyu ini (KlatenOnline, 14 Januari 2011).

Disisi lain, tradisi Saparan juga dijadikan sebagai obyek pariwisata daerah. Prosesi upacara yang dulunya penuh dengan ritual khidmat, kini sudah diselingi dengan kesenian-kesenian seperti drum band, reog, angguk, jathilan dan lainnya serta pasar malam. Secara administratif pemerintahan, tradisi upacara ini juga dikelola oleh Dinas Pariwisata Klaten dengan memungut retribusi bagi para pengunjung maupun pedagang yang berjualan disekitar tempat ini, secara realitas obyektif, tradisi Ya Qowiyu tersebut cukup menarik sebagai salah satu rangkain tujuan wisata disekitar daerah Jatinom Klaten. 


\section{KESIMPULAN}

Dalam kajiannya tentang manusia dan kebudayaan, Ernst Cassirer mendefinisikan manusia sebagai "animal symbolicum". Pemikiran simbolis dan tingkah laku simbolis merupakan ciri khas manusia dan bahwa seluruh kebudayaan manusia mendasarkan diri pada kondisi-kondisi itu. Menurut Victor Turner, simbol adalah sesuatu yang menghubungkan yang tidak tampak dengan yang tampak, dan simbol seringkali mewujud dalam kegiatan-kegiatan ritual meski kegiatan ritual dewasa ini diungkap dalam bentuk pawai, protes, demo dan bentuk lain yang ditujukan untuk kepentingan duniawi. Walau demikian kegiatan ritual yang merupakan pelestarian tradisi masih marak dilaksanakan sebagaimana pelaksanaan ritual Saparan/Yaqowiyu yang dilaksanakan tiap tahun di Jatinom, Klaten. Dari fenomena pelaksanaan ritual Yaqowiyu ini dapat kita ambil kesimpulan bahwa modernisasi tidak serta merta merubah kebudayaan suatu masyarakat menjadi modern termasuk dalam ranah pemikiran, karena rasionalisasi tidak selalu mendominasi pemikiran manusia (dalam konteks masyarakat Indonesia). Dan makna simbol akan selalu berubah seiring dengan perubahan kondisi suatu masyarakat.

\section{DAFTAR PUSTAKA}

Abdullah, Irwan. 2002. "Makna Simbolis Gunungan Kakung", dalam Simbol, Makna dan Pandangan Hidup Jawa. Analisis Gunungan pada Upacara Garebeg. Balai Kajian Sejarah dan Nilai Tradisional. Yogyakarta.

Beatty, Andrew. 2001. Variasi Agama di Jawa. Murai Kencana. Jakarta.

Dillistone, F.W. 2002. The Power of Symbols. Penerbit Kanisius. Yogyakarta.
Fajar Shodiq, Muh. 2008. Akulturasi Budaya Islam dalam Tradisi Saparan/ Yaqowiyu di Jatinom Klaten. Mahameru Press. Yogyakarta.

Geertz, Clifford. 1983. Abangan, Santri, Priyayi dalam Masyarakat Jawa. Pustaka Jaya. Jakarta.

Lombard, Denys. 2000. Nusa Jawa: Silang Budaya. Kajian Sejarah Terpadu. Bagian II: Jaringan Asia. PT Gramedia Pustaka Utama. Jakarta.

Mulyana, Deddy. 2001. Metodologi Penelitian Kualitatif: Paradigma Ilmu Komunikasi dan Ilmu Sosial Lainnya. PT. Remaja Rosda Karya.

Nasikun. 2003. "Teori Interaksionisme Simbolik". Makalah disampaikan pada Pelatihan penelitian Dosen STAIN seluruh Indonesia di Salatiga.

Suhardi. 2012. "Tafsir Kebudayaan/Teori Simbol". Diktat kuliah Tafsir Kebudayaan/Teori Simbol.

http://KlatenOnline.com/klaten/upacaraadat-ritual-yaqowiyu

http:/KlatenOnline.com/Fajar Shodiq. Solopos, 13 Februari 2009, hal.4

http://Pristality.worldpress.com/2011/01/18/ Sejarah-upacara-yaqowiyunyebar-apem di Klaten

http:/Indonesia-life.com/kolom 